\title{
ANALYTICAL DESCRIPTION OF GENETIC CONTROLLING SYSTEMS IN CELLS IN OF PROLIFERATION AND DIFFERENTIATION STATES
}

\author{
I. V. Stadnyk, D. I. Sanagursky \\ Ivan Franko National University of Lviv, 4, Hrushevskyi St., Lviv 79005, Ukraine \\ e-mail: irysjastadnyk@gmail.com
}

Paper presents kinetic models of changes in genetic controlling systems of cells in the states of cell proliferation and differentiation. It was shown that the changes in the genetic control of cells in the state of proliferation and differentiation occur at the maximal rate of reactions constants. It was built on response surfaces for each of the reaction rate constants showing what parameters of the model make the largest contribution to the value of each of them. It was established that the greatest contribution to the rate of reaction constants of changes in the genetic controlling systems of cells in the state of proliferation have histone genes and cyclin-dependent kinases, and a little less - genesstimulators of proliferation and transcription factors. In cells in differentiation a state of inhibitors of cyclin-dependent kinases, and equally transcription factors, cell cycle genes, transcription proteins genes, structural genes and hyperpolarization of the cell membrane. As a result, we got data that the value concentration of cyclin-dependent kinases and inhibitors of cyclin-dependent kinases in the cell is the trigger that determines whether a cell proliferates or differentiates. Also, it was set specific numerical value of each of the reactions rate constants which characterize changes in the genetic control of cell in the state of proliferation and differentiation.

Keywords: proliferation, differentiation, speed constant, response surfaces, genetic control.

\section{INTRODUCTION}

There are different ways of regulation of cell activity, which are attributed to genetic, biochemical and physiological levels of regulation. Within each of them there exist specific operating mechanisms, based on a sequence of certain metabolic processes. Understanding of the dynamic properties of these regulatory mechanisms can be based on system-wide approach that examines the behavior of each element of a complex system as a result of its interaction with other elements. One of the most advanced approaches is mathematical modeling. The kinetic models reflect the dynamics of changes in the intensity of various components of biological systems, and define rates of individual elementary reactions. In the basis of the environment exchange processes and internal metabolism, there is a complex network of metabolic reactions. As a result of these processes there are changes in concentrations of various substances, the number 
of certain cells, biomass of organisms, also may change other parameters, such as the value of the transmembrane potential of the cell. Changes in all of these variables over time make the kinetics of biological processes. Since all living systems are far from the thermodynamic equilibrium, they are open systems for the flow of matter and energy, and have a complex heterogeneous structure and hierarchical systems controlling processes of both internal and external environment [22].

In models, there are used systems of differential equations describing dynamic processes specific to wildlife, as well as systems of linear and nonlinear algebraic equations or inequalities. The research of modeling object and drafting of its mathematical description is to establish relationships between the characteristics of the process identify its boundary and initial conditions and formalize the process in the form of mathematical relationships. To describe deterministic, time-variable phenomena, the differential equations are often used $[6,11,18,19]$. The basic approach in kinetics and mathematical modeling of biological processes is to avoid the finding of exact analytical solutions of differential equations [22]. Multivariate conditions and non-linear relationship between parameters create difficulties in the mathematical modeling of biological processes $[5,16,23]$.

Thus, the usage of mathematical modeling of various processes allows us to study the properties of objects and determine optimal conditions for their functioning.

\section{MATERIALS AND METHODS}

On the basis of published data on the role of genes and their products in cell proliferation and differentiation, as well as on the impact of other factors, including changes in transmembrane potential on cell proliferation and differentiation, we built the kinetic model of changes in genetic controlling systems of cells in the state of proliferation and differentiation. The kinetic model shows changes at the gene level that occur both in cells in the state of proliferation and differentiation.

Changes in the genetic controlling systems of cells in the state of proliferation are shown in Fig. 1.

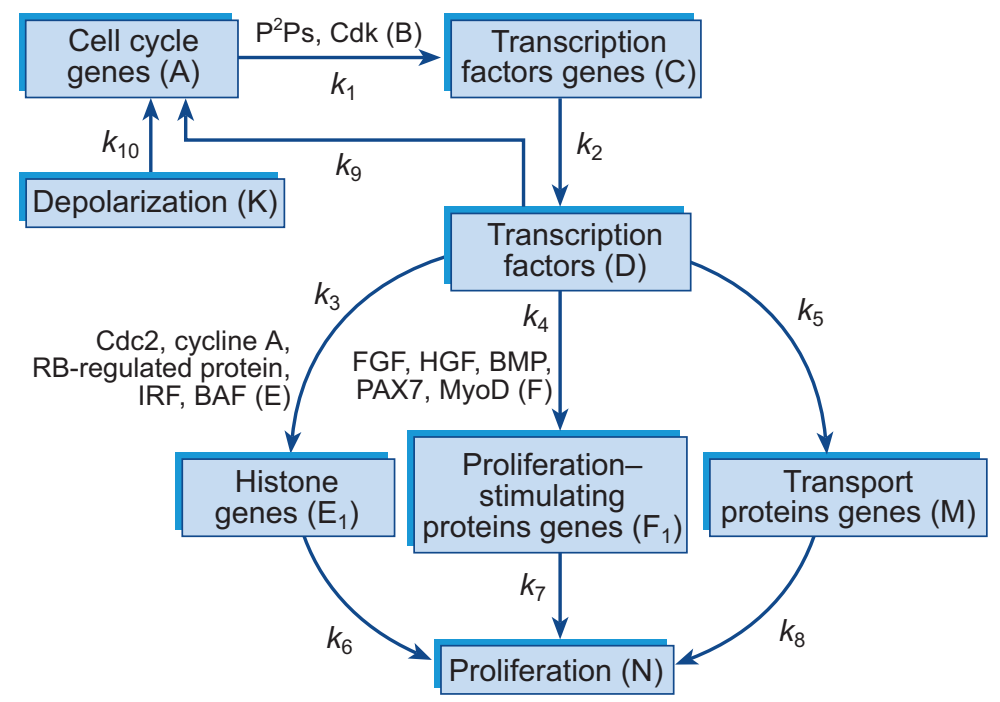

Fig. 1. Kinetic model of changes of genetic controlling systems in cells in the state of proliferation

Рис. 1. Кінетична модель змін систем генетичного контролю клітин у стані проліферації 
This diagram shows the changes that occur with genetic apparatus of cells when it enters a phase of proliferation. It is known that the cell cycle is regulated by cyclin-dependent kinases, which together with cyclin cause onset of proliferation [31].

As shown in Fig. 1, cell cycle genes indirectly through cyclin-dependent kinases in complex with cyclin [31] and specific proliferative potential proteins $\mathrm{P}^{2} \mathrm{Ps}$ [15] affect transcription proteins genes, which in turn produce various kinds of transcription factors. These transcription factors affect the number of genes that directly cause the onset of proliferation. Transcription factors can also operate on the principle of negative feedback, causing inhibitory effects on cell cycle genes by blocking their further formation.

It was found proximal promoter element of histone $\mathrm{H} 4$, designated as Site II, which mediates the transcriptional control of the cell cycle. Factor that interacts with the Site II includes cdc2, cyclin A, RB-regulated protein and interferon regulatory factors (IRFs). Proliferation is only possible due to the integration of this factor to Site II. When this factor is not associated with Site II, the differentiation is initiated [23]. Another study reviewed a protein complex BAF (Brahma associated factor), and how it controls coiling of DNA around histone complex of chromosome [10]. Because BAF changes the structure of the DNA helix, it controls the access of transcription factors to these genes. Therefore, this factor is required for the regulation of the passage of proliferation. Thus, based on these studies and by Fig. 1, it can be argued that the transcription factors mediate activation of histone genes, resulting in the onset of proliferation.

In another study [1], it was found that fibroblast growth factor (FGF) stimulates and controls the proliferation of satellite cells, through the activation of proliferation-stimulating proteins genes, synergistically with hepatocyte growth factor (HGF) [1]. Other authors $[20,28,30]$ found that activated satellite cells in the state of proliferation express regulatory factors Pax7 and MyoD, which are markers of cells in the state of proliferation. Moreover, when studying the osteogenic effect of bone morphogenesis proteins (BMP), the authors [14] analyzed the role of these proteins in the proliferation of satellite cells. The authors found that BMP signaling stimulates cell proliferation and inhibits their differentiation. Thus, it can be argued that a number of regulatory factors (FGF, HGF, Pax7 and MyoD) and proteins (BMP) through effects on proliferation-stimulating proteins genes also lead to differentiation.

It was also found [12] that the transcription factors mediate activation of transport proteins genes playing a significant role in the onset of proliferation.

Summarizing the data and addressing to Fig. 1, it can be argued that a number of transcription factors directly or indirectly affect the histone genes, proliferation-stimulating proteins genes and transport proteins genes, and thus trigger the onset of proliferation.

In addition it was found in studies [24, 25] that the value of the transmembrane potential directly affects the possibility of initiation of proliferation or differentiation. So the authors have found that proliferating cells show strong depolarized level of membrane potential and cells in the state of differentiation - much hyperpolarized level of membrane potential. A possible explanation for this phenomenon may be that the highly polarized level of transmembrane potential (TMP) blocks resting somatic cells that are in $G_{1}$ phase of the cell cycle from entry into $S$ phase of DNA synthesis, thus inhibiting mitosis [4]. Later it was suggested [2] that there may be a threshold level of TMP, which serves as a boundary or trigger of DNA synthesis. Depolarization is caused by increasing of cell permeability to $\mathrm{Na}^{+}$ions [17]. Thus depolarization directly affects the onset of proliferation: depolarized membrane potential, affecting the genes of the cell cycle, launches a whole cascade of transformations depicted in Fig. 1.

ISSN 1996-4536 (print) • ISSN 2311-0783 (on-line) • Біологічні Студії / Studia Biologica • 2015 • Том 9/№1 • С. 67-84 
Next, we performed a mathematical description of the model which by a differential equations system describes changes in each parameter over time. This system of differential equations is presented below:

$$
\begin{aligned}
& \frac{d A}{d t}=-k_{1} A-k_{9} D+k_{10} \\
& \frac{d B}{d t}=-k_{1} B \\
& \frac{d C}{d t}=k_{1}(A)(B)-k_{2} \\
& \frac{d D}{d t}=k_{2} C+k_{3} D-k_{4} D+k_{5} D \\
& \frac{d E}{d t}=k_{3} D-k_{6}\left(E E_{1}\right) \\
& \left\{\frac{d E_{1}}{d t}=-k_{6} E_{1}\right. \\
& \frac{d F}{d t}=k_{4} D-k_{7}\left(F F_{1}\right) \\
& \frac{d F_{1}}{d t}=-k_{7} F_{1} \\
& \frac{d M}{d t}=k_{5} D-k_{8} M \\
& \frac{d N}{d t}=k_{6}\left(E E_{1}\right)+k_{7}\left(F F_{1}\right)+k_{8} M \\
& \frac{d K}{d t}=-k_{10} K
\end{aligned}
$$

Changes in genetic control in cells in the state of differentiation are shown in Fig. 2.

This diagram shows the processes that occur with a cell that enters a phase of differentiation. As shown in Fig. 2, the cell cycle genes interact with the inhibitors of cyclin-dependent kinases, thereby blocking cell cycle progression and promote the onset of differential processes. So it was found [9] that the activity of Cdk-cyclin complexes may be inhibited by binding of Cdk inhibitors (Cdl), which inhibit all Cdkcyclin complexes of $\mathrm{G}_{1}$ phase. The fact that $\mathrm{Cdl}$ act as regulators in many differentiating tissues, suggests that these proteins may play a role in getting out of the cycle of proliferation and onset of differentiation.

Such blocking of cyclin-dependent kinases leads to the fact that the transcription proteins genes produce other transcription factors than during proliferation. These factors are: Osf2, Omd i Ogn. They were discovered as the potential factors in the differentiation of skeletal muscle cells [14]. Transcription factors play an indirect role in the onset of differentiation through the activation of a number of structural genes (Fig. 2), including angiogenesis proteins genes, receptor proteins genes and channel proteins genes

[12]. The products of expression of the structural genes are structural proteins. So it was found increased expression of BMP inhibitors Chordin and Myogenin that promote the onset of differentiation and block proliferation [7]. Expression of the cell structural genes and the presence of structural proteins directly indicate the onset of differential program. It was found [12] that differentiation can also be induced by CAMP and retinoic acid.

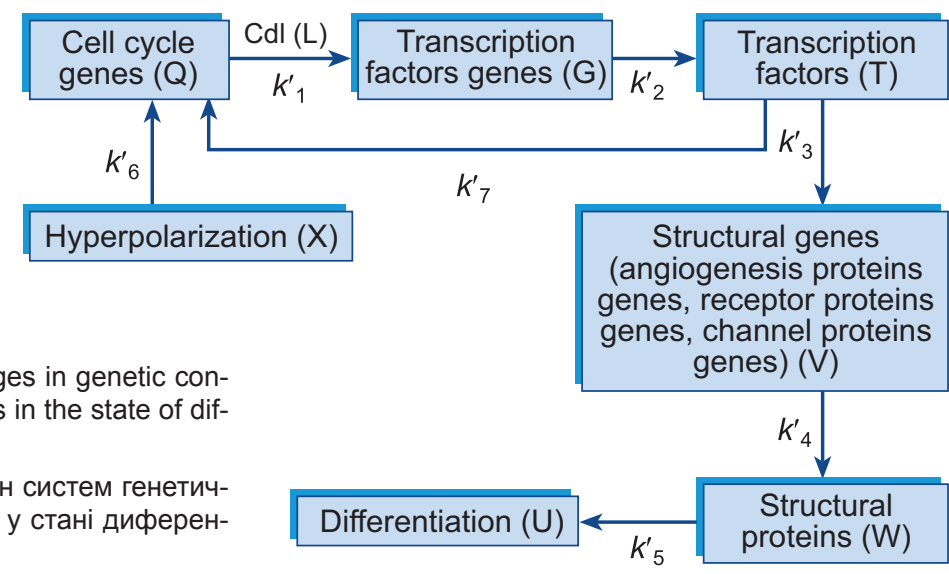

ISSN 1996-4536 (print) • ISSN 2311-0783 (on-line) • Біологічні Студії / Studia Biologica • 2015 • Том 9/№1 • C. 67-84 
Transcription factors, as well as during cell proliferation, may act as negative regulators of their activity. They can communicate with the cell cycle genes and inhibit their activity, thereby blocking its own formation.

As already mentioned above, the cells in the state of differentiation have much hyperpolarized membrane potential [24, 25]. Hyperpolarization may be caused by increased permeability of the cell membrane to $\mathrm{K}^{+}$ions. So, hyperpolarization causes blockage of the cell cycle and the onset of differential program.

Thus, Fig. 2 shows a cascade of changes that occur during the transition of cell from the state of proliferation to the state of differentiation.

It was also made the mathematical description of the kinetic model of changes in genetic controlling systems of cells in the state of differentiation. Accordingly, the following system of differential equations describes this model.

The following differential equations systems were solved by numerical integration [16] using MATLAB 7.0.1.

As seen from the Fig. 1-2, each reaction is characterized by its own reaction rate constant, and the intensity of each model parameter depends on the intensity of the other parameters and rate constants. But the solutions of these equations do not provide information from which variables depends each of the reaction rate constants and in what range of values they are changing. For specifying exactly which variables make the largest contribution to each of the reaction rate constants, using Box-Wilson method, we constructed response surfaces for all of the reaction rate constants. Construction of response surfaces was carried out using a specially created computer program Octave, which determined what parameters make the largest contribution to each of the rate constants, by the method of selection of about 10,000 combinations of the mutual influence of all parameters on the values of reaction rate constants and to each other.

However, the response surfaces do not provide a way

$$
\left\{\begin{array}{l}
\frac{d Q}{d t}=-k_{1}^{\prime} Q+k_{6}^{\prime} X-k_{7}^{\prime} T \\
\frac{d L}{d t}=-k_{1}^{\prime} L \\
\frac{d G}{d t}=k_{1}^{\prime}(Q L)-k_{2}^{\prime} G \\
\frac{d T}{d t}=k_{2}^{\prime} G-k_{3}^{\prime} T-k_{7}^{\prime} T \\
\frac{d V}{d t}=k_{3}^{\prime} T-k_{4}^{\prime} V \\
\frac{d W}{d t}=k_{4}^{\prime} V-k_{5}^{\prime} W \\
\frac{d U}{d t}=k_{5}^{\prime} W \\
\frac{d X}{d t}=-k_{6}^{\prime} X
\end{array}\right.
$$
to visually determine the maximal value of the constant by which the rate of conversions in the system is maximal. To determine the maximal value of the constant it was necessary to transform the obtained response surfaces into the linear dependence (linearization method by Lineweaver-Burk) and find the point of intersection of the line with the coordinate axes. The point of intersection of the line formed by the abscissa is the desired maximal value of the rate constant, i.e. $k_{\max }$.

\section{RESULTS AND DISCUSSION}

Solutions of equations describing the changes in the genetic control of cells in the state of proliferation and differentiation are presented graphically (Fig. 3 and 4). The obtained results show time changes of the initial conditions of the parameters $A, B, C, D, E$, $E_{1}, F, F_{1}, M, N, K$ (first system) and $Q, L, G, T, V, W, U, X$ (second system), with the reaction rate constants $k_{1}-k_{10}$ and $k_{1}^{\prime}-k_{7}^{\prime}$ (first and second system, respectively). The values of the initial conditions display the intensity of each parameter (gene, protein, another factor of the kinetic model) in the cell. To calculate these values it was chosen initial conditions and rate constants of reactions presented in Tab. 1 and 2, respectively:

ISSN 1996-4536 (print) • ISSN 2311-0783 (on-line) • Біологічні Студії / Studia Biologica • 2015 • Том 9/№1 • С. 67-84 
Table 1. The value of the initial conditions of the changes intensity of the cell parameters for two systems

Таблиця 1. Значення початкових умов зміни інтенсивності параметрів клітини для двох систем

\begin{tabular}{c|c|c|c}
\hline $\begin{array}{c}\text { Parameter of the } \\
\text { I equation system }\end{array}$ & $\begin{array}{c}\text { Initial conditions } \\
\text { (intensity of the } \\
\text { parameter in the cell, \%) }\end{array}$ & $\begin{array}{c}\text { Parameter of the } \\
\text { Il equation system }\end{array}$ & $\begin{array}{c}\text { Initial conditions } \\
\text { (intensity of the } \\
\text { parameter in the cell, \%) }\end{array}$ \\
\hline A & 0.2 & $\mathrm{Q}$ & 0.2 \\
$\mathrm{~B}$ & 0.04 & $\mathrm{~L}$ & 0.017 \\
$\mathrm{C}$ & 10 & $\mathrm{G}$ & 10 \\
$\mathrm{D}$ & 10 & $\mathrm{~T}$ & 10 \\
$\mathrm{E}$ & 0.017 & $\mathrm{~V}$ & 30 \\
$\mathrm{E}_{1}$ & 0.02 & $\mathrm{~W}$ & 45 \\
$\mathrm{~F}$ & 0.017 & $\mathrm{U}$ & 30 \\
$\mathrm{~F}_{1}$ & 0.02 & $\mathrm{X}$ & 35 \\
$\mathrm{M}$ & 0.03 & & \\
$\mathrm{~N}$ & 45 & & \\
$\mathrm{~K}$ & 50 & & \\
\hline
\end{tabular}

Table 2. Values of reaction rate constants for two equation systems

Таблиця 1. Значення величин констант швидкостей реакцій для двох систем рівнянь

\begin{tabular}{c|c|c|c|c|c}
\hline$k$ I I system & Min & Max & $k^{\prime}$, II system & Min & Max \\
\hline$k_{1}$ & $10^{-8}$ & 0.25 & $k^{\prime}{ }_{1}$ & $10^{-8}$ & 0.25 \\
$k_{2}$ & $10^{-6}$ & 1 & $k^{\prime}{ }$ & $10^{-6}$ & 1 \\
$k_{3}$ & $10^{-8}$ & 0.3 & $k^{\prime}{ }$ & $10^{-7}$ & 0.6 \\
$k_{4}$ & $10^{-8}$ & 0.3 & $k^{\prime}{ }_{4}$ & $10^{-6}$ & 1 \\
$k_{5}$ & $10^{-8}$ & 0.3 & $k^{\prime}{ }$ & $10^{-7}$ & 0.6 \\
$k_{6}$ & $10^{-6}$ & 0.9 & $k_{6}^{\prime}$ & $10^{-8}$ & 0.25 \\
$k_{7}$ & $10^{-6}$ & 0.9 & $k^{\prime}{ }_{7}$ & $10^{-7}$ & 0.75 \\
$k_{8}$ & $10^{-6}$ & 0.9 & & & \\
$k_{9}$ & $10^{-8}$ & 0.25 & & & \\
$k_{10}$ & $10^{-7}$ & 0.75 & & & \\
\hline
\end{tabular}

The following time changes in the parameters intensity of the cell in the state of proliferation and differentiation are presented in Fig. 3 and 4, respectively:

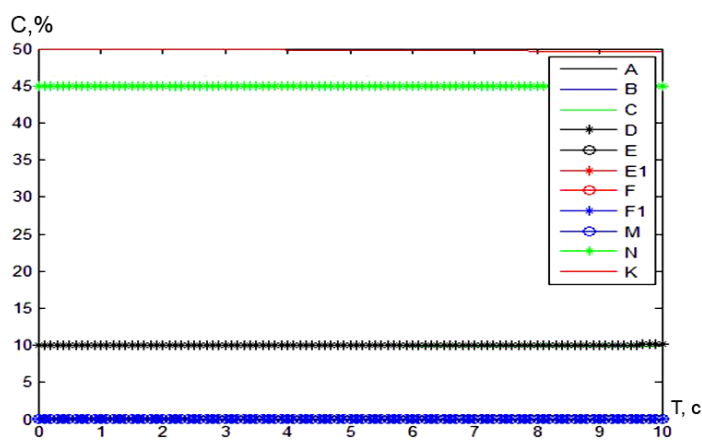

Fig. 3 Time changes in the parameters intensity at the minimal reactions rate constants in the cell in the state of proliferation

Рис. 3. Зміна інтенсивності параметрів з часом при мінімальних значеннях констант швидкостей реакцій у клітині у стані проліферації

ISSN 1996-4536 (print) • ISSN 2311-0783 (on-line) • Біологічні Студії / Studia Biologica • 2015 • Том 9/№1 • C. 67-84 
Fig. 4. Time changes in the parameters intensity at the minimal reactions rate constants in the cell in the state of differentiation

Рис. 4. Зміна інтенсивності параметрів з часом при мінімальних значеннях констант швидкостей реакцій у клітині у стані диференціації

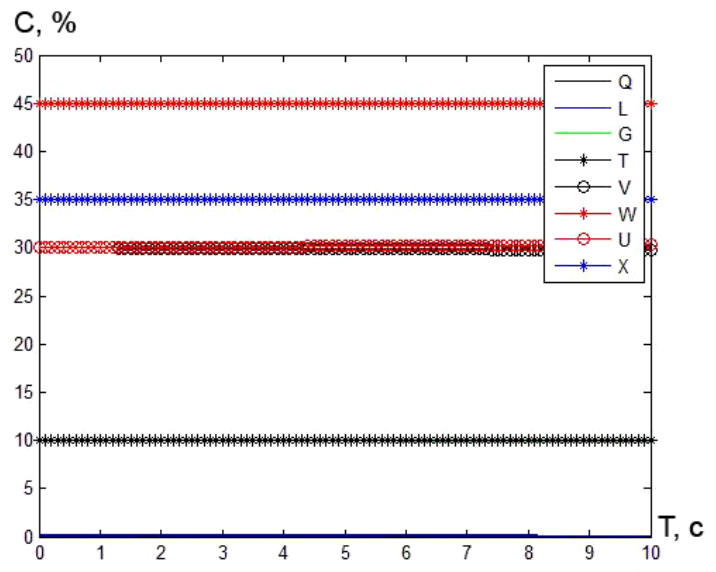

As shown in Fig. 3 and 4, at the minimal values of reactions rate constants it is observed continuous intensity of all the parameters during all time, both in the cells in the state of proliferation and differentiation, which is not typical of living systems.

The case when the processes run at maximal values of reaction rate constants in the cells in the state of proliferation and differentiation, is shown in Fig. 5 and 6 (for cells in the state of proliferation and differentiation, respectively).

Fig. 5. Time changes in the parameters intensity at the maximal reactions rate constants in the cell in the state of proliferation

Рис. 5. Зміна інтенсивності параметрів з часом при максимальних значеннях констант швидкостей реакцій у клітині у стані проліферації

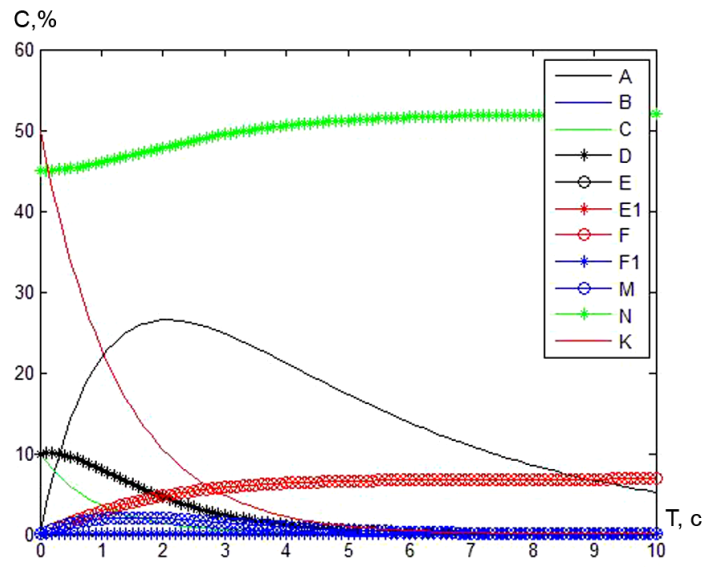

As shown in Fig. 5 and 6, there is a non-linear time changes in the parameter intensity in the cell. So when the cell is in the state of proliferation (Fig. 5), which is accompanied by an increase in the transmembrane potential of the cell (depolarization of the cell membrane), it is seen an increase in the expression of histone genes and transport proteins genes and of the concentrations of FGF, HGF, BMP and MyoD. On the other hand, it is seen a decrease in the expression of transcription proteins genes, and therefore of the concentrations of transcription factors and cyclin A, RB-regulated protein, BAF, IRF. Expression of the proliferation-stimulating proteins genes and the concentration of cyclin-dependent kinases remain unchanged or these changes are minor. The intensity of the expression of cell cycle genes first increases and then decreases. The obtained results are confirmed by the literature [1, 7, 12-14, 20, 21, 26-28]. 


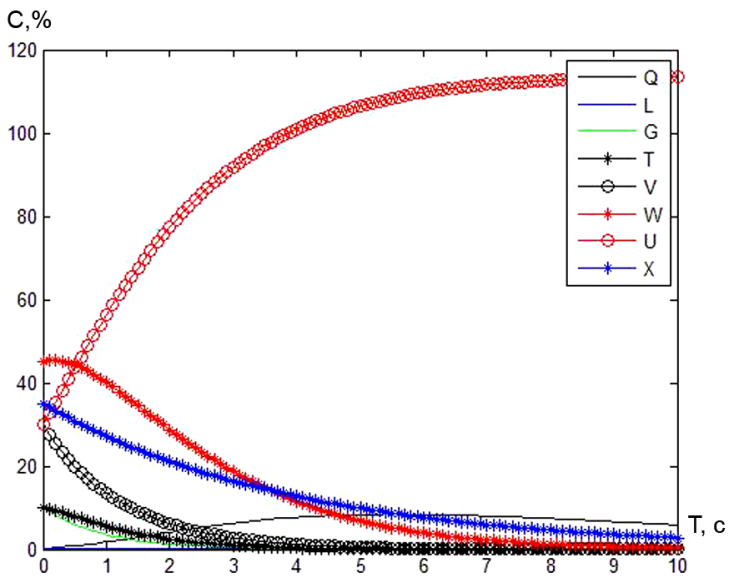

Fig. 6. Time changes in the parameters intensity at the maximal reactions rate constants in the cell in the state of differentiation

Рис. 6. Зміна інтенсивності параметрів з часом при максимальних значеннях констант швидкостей реакцій у клітині у стані диференціації

Time changes of the parameters intensity in the cell in the state of differentiation (Fig. 6) are also non-linear. So when the cell is in the state of differentiation, which is accompanied by a decrease in the transmembrane potential of the cell (hyperpolarization of the cell membrane), it is observed an increase in the expression of the cell cycle genes. In contrast, it is seen a decrease in the expression of transcription proteins genes and structural genes, and thus in the concentration of transcription factors and structural proteins. The concentrations of inhibitors of cyclin-dependent kinases, as the concentrations of cyclin-dependent kinases during cell proliferation remain unchanged or these changes are minor. These results were also confirmed by a number of experimental data in the literature [3, 8, 9, 29-31].

Thus, as shown in Fig. 5 and 6, there is a nonlinear time changes in the activity of genes, proteins or other factors at maximal values of reaction rate constants, which is a characteristic of the living system. Therefore, it can be argued that the changes in the genetic control of cells in the state of proliferation and differentiation occur at the maximal values of reaction rate constants that reflect these changes.

Referring to the differential equations systems describing the changes in the genetic control of cells in the state of proliferation and differentiation, we can see that each of the rate constants $\left(k_{1}-k_{10}\right.$ (I system), $k_{1}^{\prime}-k_{7}^{\prime}$ (II system)) depends on certain variables (A, B, C, D, E, E $, ~ F, F_{1}, M, N, K$ (I system), Q, L, G, T, V, W, X (II system)). In fact, each of them depends on all 11 parameters (for cell in the state of proliferation) or 8 parameters (for cells in the state of differentiation) because all equations are interrelated. Therefore, we created a special computer program for constructing response surfaces for each constant to determine which variables make the largest contribution to each rate constant. The resulting response surfaces are shown in Fig. 7 (reaction rate constants of changes in the cells in the state of proliferation) and Fig. 8 (reaction rate constants of changes in the cells in the state of differentiation).

These response surfaces show the spatial temporal dependence of the reaction rate constants of changes in the genetic controlling systems on the intensity of the definite model parameters.

The obtained data are presented in Tab. 3 and 4.

As shown in Tab. 3, the largest contribution to the value of constants $k_{1}, k_{7}$ and $k_{8}$ have such parameters as proliferation-stimulating proteins genes and histone genes. 

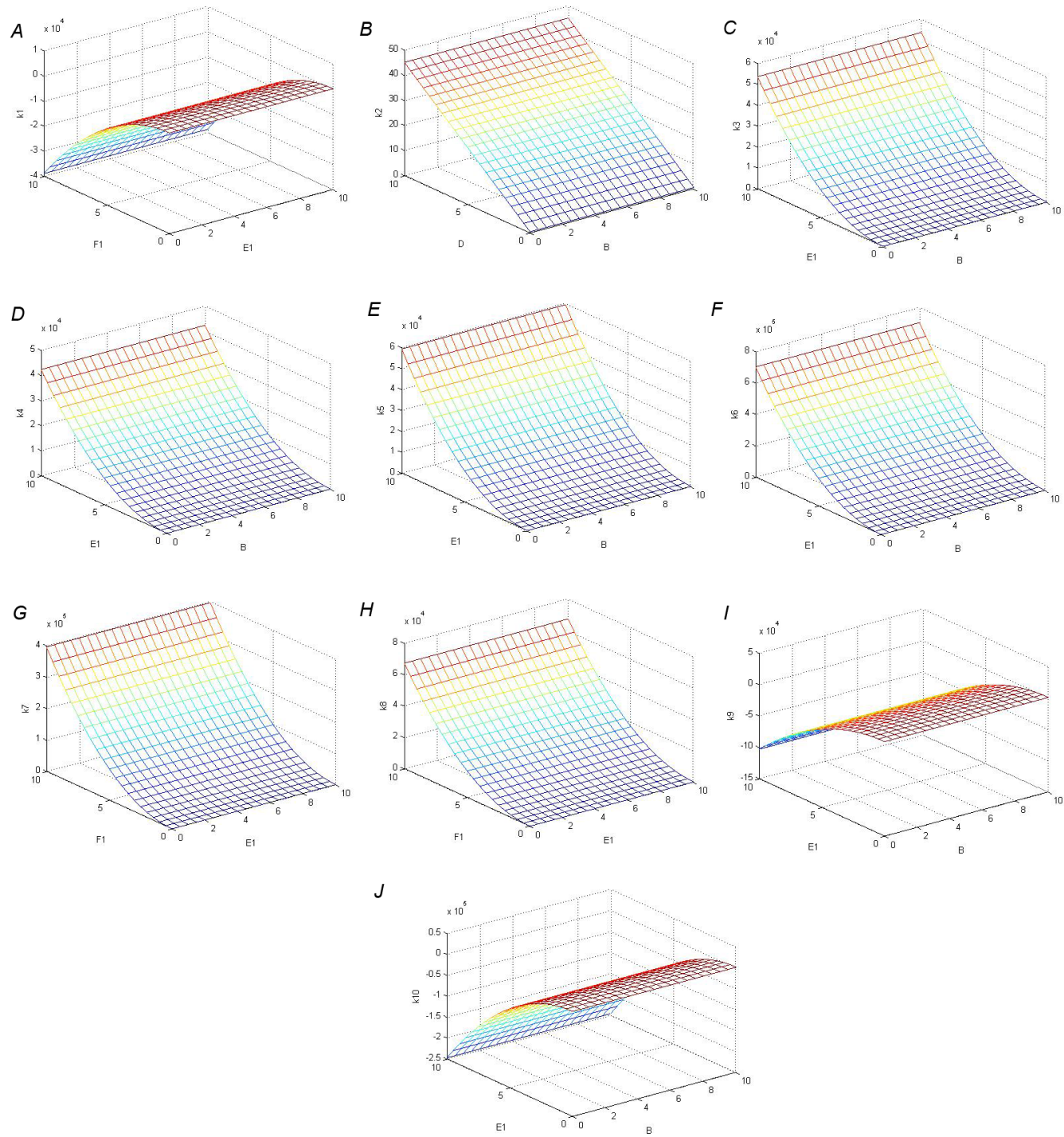

Fig. 7. Response surfaces for reaction rate constants of changes in genetic controlling systems of the cells in the state of proliferation: $A$ - response surface for rate constant $k_{1}$; $B$-response surface for rate constant $k_{2} ; C$ - response surface for rate constant $k_{3} ; D$ - response surface for rate constant $k_{4} ; E-$ response surface for rate constant $k_{5} ; F$ - response surface for rate constant $k_{6} ; G$ - response surface for rate constant $k_{7} ; H$ - response surface for rate constant $k_{8} ; I$ - response surface for rate constant $k_{9} ; J$ - response surface for rate constant $k_{10}$

Рис. 7. Поверхні відклику для констант швидкостей реакцій перетворень у системах генетичного контролю клітин у стані проліферації: $A$ - поверхня відклику для константи швидкості $k_{1}$; $B$ - поверхня відклику для константи швидкості $k_{2} ; C$ - поверхня відклику для константи швидкості $k_{3} ; D-$ поверхня відклику для константи швидкості $k_{4} ; E$ - поверхня відклику для константи швидкості $k_{5} ; F-$ поверхня відклику для константи швидкості $k_{6} ; G$ - поверхня відклику для константи швидкості $k_{7} ; H$ - поверхня відклику для константи швидкості $k_{8} ; l$ - поверхня відклику для константи швидкості $k_{9} ; J$ - поверхня відклику для константи швидкості $k_{10}$ 

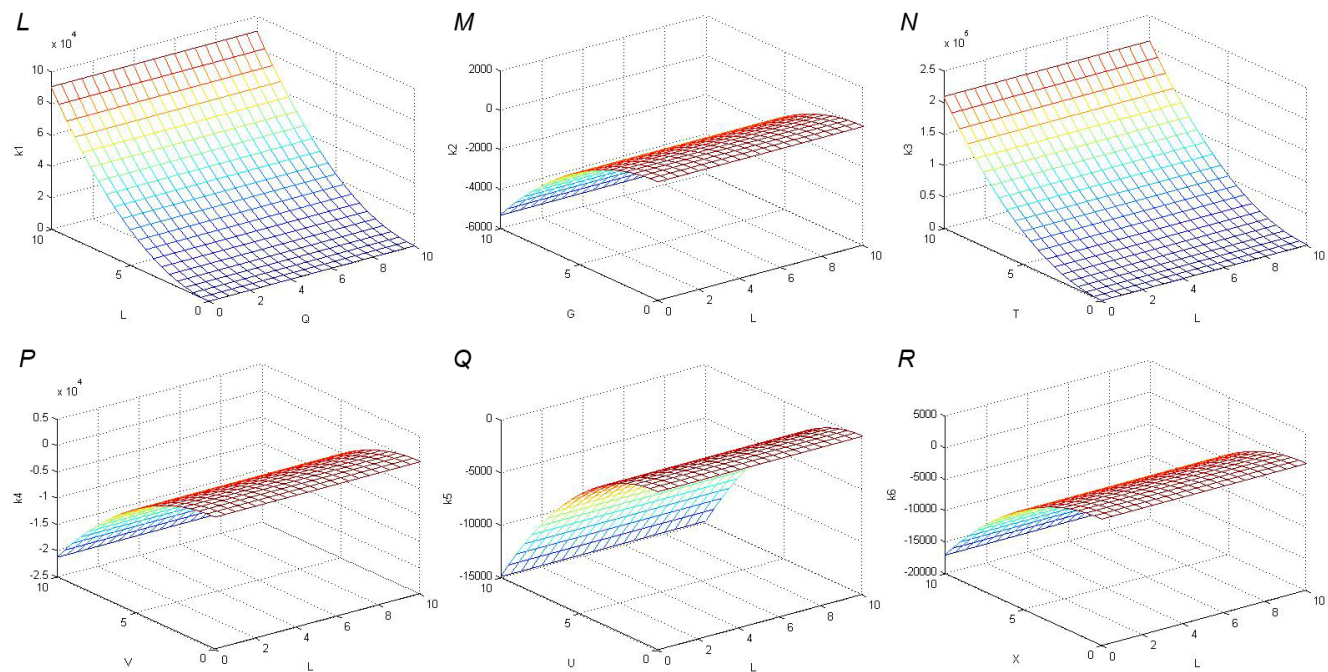

$Q$

$R$
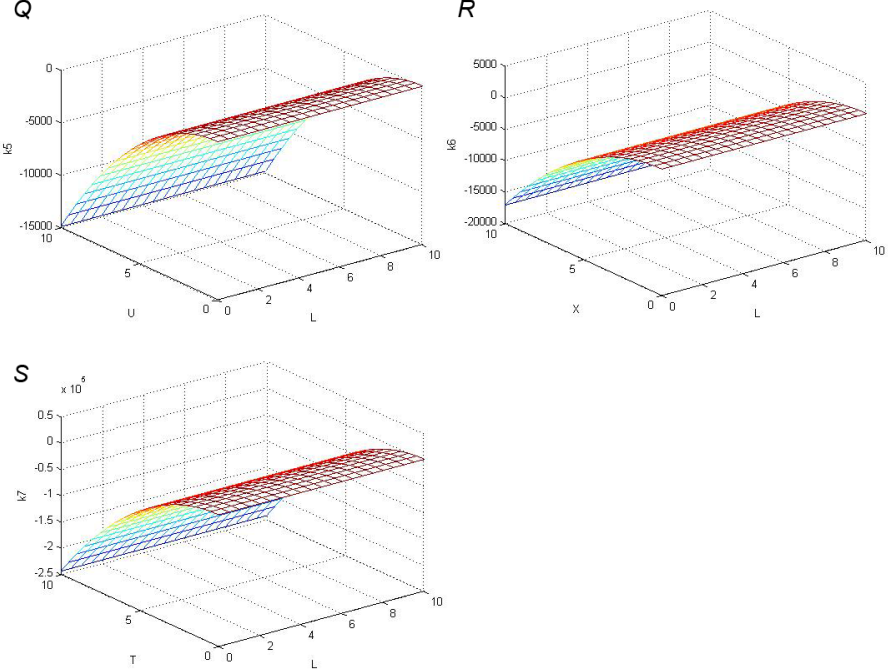

Fig. 8. Response surfaces for reaction rate constants of changes in genetic controlling systems of the cells in the state of differentiation: $L$ - response surface for rate constant $k_{1}^{\prime} ; M$ - response surface for rate constant $k_{2}^{\prime} ; N$ - response surface for rate constant $k_{3}^{\prime} ; P$ - response surface for rate constant $k_{4}^{\prime}$; $Q$ - response surface for rate constant $k_{5}^{\prime} ; R$ - response surface for rate constant $k_{6}^{\prime} ; S$ - response surface for rate constant $k_{7}^{\prime}$

Рис. 8. Поверхні відклику для констант швидкостей реакцій перетворень у системах генетичного контролю клітин у стані диференціації: $L$ - поверхня відклику для константи швидкості $k_{1}^{\prime} ; M-$ поверхня відклику для константи швидкості $k_{2}^{\prime} ; N-$ поверхня відклику для константи швидкості $k_{3}^{\prime}$; $P$ - поверхня відклику для константи швидкості $k_{4}^{\prime} ; Q-$ поверхня відклику для константи швидкості $k_{5}^{\prime} ; R$ - поверхня відклику для константи швидкості $k_{6}^{\prime} ; S-$ поверхня відклику для константи швидкості $k_{7}^{\prime}$

In the value of the constant $k_{2}$ - transcription factors and cyclin-dependent kinases; while in the value of constants $k_{3}, k_{4}, k_{5}, k_{6}, k_{9}$ and $k_{10}$ - histone genes and cyclin-dependent kinases. Thus, the greatest contributions to the reaction rate constants of changes in the genetic controlling systems of the cell in the state of proliferation have histone genes and cyclin-dependent kinases, and a little less - proliferation-stimulating proteins genes and transcription factors. Parameters such as cell cycle genes, transcription proteins genes, protein complexes, transport proteins genes and depolarization have no significant effect on the rate of transformation in the cells in the state of proliferation.

Regarding to the cells in the state of differentiation (Tab. 4), the largest contribution to the value of the constant $k_{1}^{\prime}$ make such parameters as inhibitors of cyclin-dependent kinases and cell cycle genes; to the value of $k_{2}^{\prime}$ - transcription proteins genes and inhibitors of cyclin-dependent kinases; to $k_{3}^{\prime}$ - transcription factors and inhibitors of cyclin-dependent 
kinases; $k_{4}^{\prime}-$ structural genes and inhibitors of cyclin-dependent kinases; $k_{5}^{\prime}-$ differentiation and inhibitors of cyclin-dependent kinases; $k_{6}^{\prime}$ - hyperpolarization and inhibitors of cyclin-dependent kinases; and $k_{7}^{\prime}$ - transcription factors and inhibitors of cyclin-dependent kinases. As seen from the results, the greatest contributions to all constants have inhibitors of cyclin-dependent kinases. On equal level contribute: transcription factors; cell cycle genes; transcription proteins genes; structural genes and hyper polarization of the cell membrane. The effects of structural proteins on the rate of changes were not found.

Table 3. Parameters that have the major contribution to the value of the reaction rate constant in the cell in the state of proliferation

Таблиця 3. Параметри, що вносять найбільший вклад у величину констант швидкостей реакцій у клітинах у стані проліферації

\begin{tabular}{c|c|c}
$\begin{array}{c}\text { Rate } \\
\text { constant }\end{array}$ & $\begin{array}{c}\text { Marking of parameters that } \\
\text { have the major contribution }\end{array}$ & \multicolumn{1}{c}{ Parameters that have the major contribution } \\
\hline$k_{1}$ & $\mathrm{~F}_{1}, \mathrm{E}_{1}$ & Proliferation-stimulating proteins genes, histone genes \\
$k_{2}$ & $\mathrm{D}, \mathrm{B}$ & Transcription factors, cyclin-dependent kinases \\
$k_{3}$ & $\mathrm{E}_{1}, \mathrm{~B}$ & Histone genes, cyclin-dependent kinases \\
$k_{4}$ & $\mathrm{E}_{1}, \mathrm{~B}$ & Histone genes, cyclin-dependent kinases \\
$k_{5}$ & $\mathrm{E}_{1}, \mathrm{~B}$ & Histone genes, cyclin-dependent kinases \\
$k_{6}$ & $\mathrm{E}_{1}, \mathrm{~B}$ & Histone genes, cyclin-dependent kinases \\
$k_{7}$ & $\mathrm{~F}_{1}, \mathrm{E}_{1}$ & Proliferation-stimulating proteins genes, histone genes \\
$k_{8}$ & $\mathrm{~F}_{1}, \mathrm{E}_{1}$ & Proliferation-stimulating proteins genes, histone genes \\
$k_{9}$ & $\mathrm{E}_{1}, \mathrm{~B}$ & Histone genes, cyclin-dependent kinases \\
$k_{10}$ & $\mathrm{E}_{1}, \mathrm{~B}$ & Histone genes, cyclin-dependent kinases \\
\hline
\end{tabular}

Table 4. Parameters that have the major contribution to the value of the reaction rate constant in the cell in the state of differentiation

Таблиця 4. Параметри, що роблять найбільший вклад у величину констант швидкостей реакцій у клітинах у стані диференціації

\begin{tabular}{|c|c|c|}
\hline $\begin{array}{c}\text { Rate } \\
\text { constant }\end{array}$ & $\begin{array}{l}\text { Marking of parameters that } \\
\text { have the major contribution }\end{array}$ & Parameters that have the major contribution \\
\hline$k_{1}^{\prime}$ & $L, Q$ & Inhibitors of cyclin-dependent kinases, cell cycle genes \\
\hline$k_{2}^{\prime}$ & $\mathrm{G}, \mathrm{L}$ & $\begin{array}{l}\text { Transcription proteins genes, inhibitors of cyclin-dependent } \\
\text { kinases }\end{array}$ \\
\hline$k_{3}^{\prime}$ & $\mathrm{T}, \mathrm{L}$ & Transcription factors, inhibitors of cyclin-dependent kinases \\
\hline$k_{4}^{\prime}$ & $\mathrm{V}, \mathrm{L}$ & Structural genes, inhibitors of cyclin-dependent kinases \\
\hline$k_{5}^{\prime}$ & $U, \mathrm{~L}$ & Differentiation, inhibitors of cyclin-dependent kinases \\
\hline$k_{6}^{\prime}$ & $X, L$ & Hyperpolarization, inhibitors of cyclin-dependent kinases \\
\hline$k_{7}^{\prime}$ & $\mathrm{T}, \mathrm{L}$ & Transcription factors, inhibitors of cyclin-dependent kinases \\
\hline
\end{tabular}

From the response surfaces, we found which parameters $\left(A, B, C, D, E, E_{1}, F, F_{1}\right.$, $M, N, K, Q, L, G, T, V, W, U$, and $X$ ) make the largest contribution to the value of each of the reaction rate constants. However, they do not give us possibility to define a specific

ISSN 1996-4536 (print) • ISSN 2311-0783 (on-line) • Біологічні Студії / Studia Biologica • 2015 • Том 9/№1 • С. 67-84 
value of each of the reaction rate constants. To find this value, we used the LineweaverBurk plot to manage to determine the value of $k_{\max }$ at the intersection of the line with the axis of ordinates.

After the digitization of the response surfaces and their subsequent linearization the following graphic dependences presented in Fig. 9 and 10 were obtained.

For each graphic has been found the point of intersection of the line with the ordinate axis $\left(k_{\max }\right)$. All values were determined by the module.

The numerical values of all $k_{\max }$ are presented in Tab. 5 and 6.

Table 5. Values of reaction rate constants of changes in genetic controlling systems in the cells in the state of proliferation

Таблиця 5. Величини констант швидкостей реакцій змін систем генетичного контролю клітин у стані проліферації

\begin{tabular}{c|c}
\hline $\begin{array}{c}\text { Reaction rate constants of changes in genetic } \\
\text { controlling systems in the cells in the state } \\
\text { of proliferation }\end{array}$ & $\begin{array}{c}\text { Values of reaction rate constants of changes } \\
\text { in genetic controlling systems in the cells } \\
\text { in the state of proliferation }\end{array}$ \\
\hline$k_{1}$ & 0.375 \\
$k_{2}$ & 0.15 \\
$k_{3}$ & 0.3 \\
$k_{4}$ & 0.375 \\
$k_{5}$ & 0 \\
$k_{6}$ & 0.3 \\
$k_{7}$ & 0.35 \\
$k_{8}$ & 0.35 \\
$k_{9}$ & 0.225 \\
$k_{10}$ & 0.4 \\
\hline
\end{tabular}

Table 6. Values of reaction rate constants of changes in genetic controlling systems in the cells in the state of differentiation

Таблиця 6. Величини констант швидкостей реакцій змін систем генетичного контролю клітин у стані диференціації

\begin{tabular}{c|c}
\hline $\begin{array}{c}\text { Reaction rate constants of changes in genetic } \\
\text { controlling systems in the cells in the state } \\
\text { of differentiation }\end{array}$ & $\begin{array}{c}\text { Values of reaction rate constants of changes } \\
\text { in genetic controlling systems in the cells } \\
\text { in the state of differentiation }\end{array}$ \\
\hline$k_{1}^{\prime}$ & 0.25 \\
$k_{2}^{\prime}$ & 0.15 \\
$k_{3}^{\prime}$ & 0.4 \\
$k_{4}^{\prime}$ & 0.425 \\
$k_{5}^{\prime}$ & 0.9 \\
$k_{6}^{\prime}$ & 0.4 \\
$k_{7}^{\prime}$ & 0.45 \\
\hline
\end{tabular}

Substituting the obtained exact values of reaction rate constants to the solutions of our differential equations systems, we obtained graphically time changes in the parameters intensity of the kinetic model of changes in genetic controlling systems of the cells. Dependence for cells in the state of proliferation and differentiation are shown in Fig. 11 and 12 , respectively. 

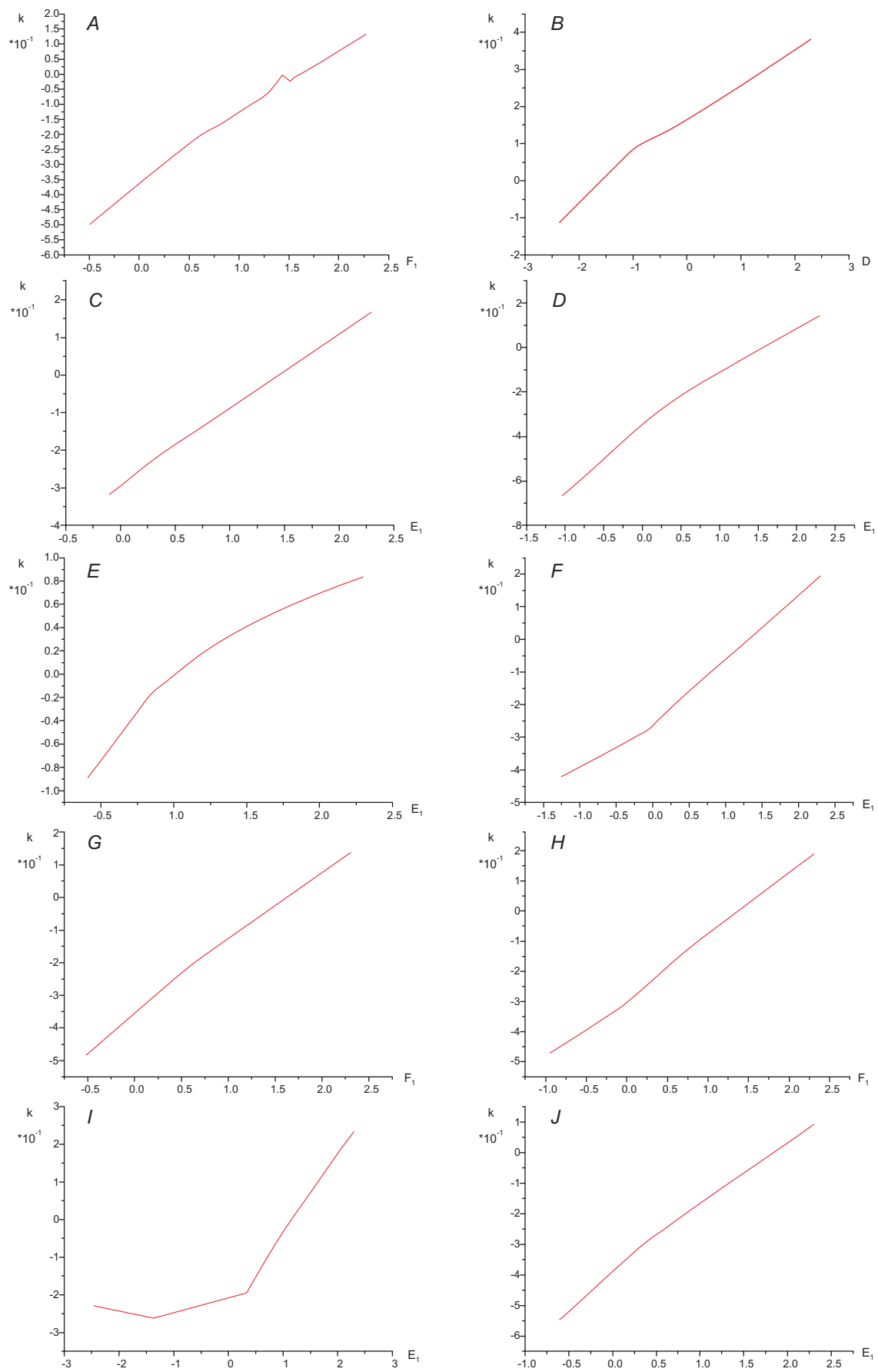

Fig. 9. Linearized response surfaces for reaction rate constants of changes in genetic controlling systems in the cells in the state of proliferation: $k_{1}(A) ; k_{2}(B) ; k_{3}(C) ; k_{4}(D) ; k_{5}(E) ; k_{6}(\mathrm{~F}) ; k_{7}(G) ; k_{8}(H) ; k_{9}(I) ; k_{10}(J)$

Рис. 9. Лінеаризовані поверхні відклику для констант швидкостей перетворень у системах генетичного контролю клітин у стані проліферації: $k_{1}(A) ; k_{2}(B) ; k_{3}(C) ; k_{4}(D) ; k_{5}(E) ; k_{6}(F) ; k_{7}(G) ; k_{8}(H) ; k_{9}(I) ; k_{10}(J)$ 

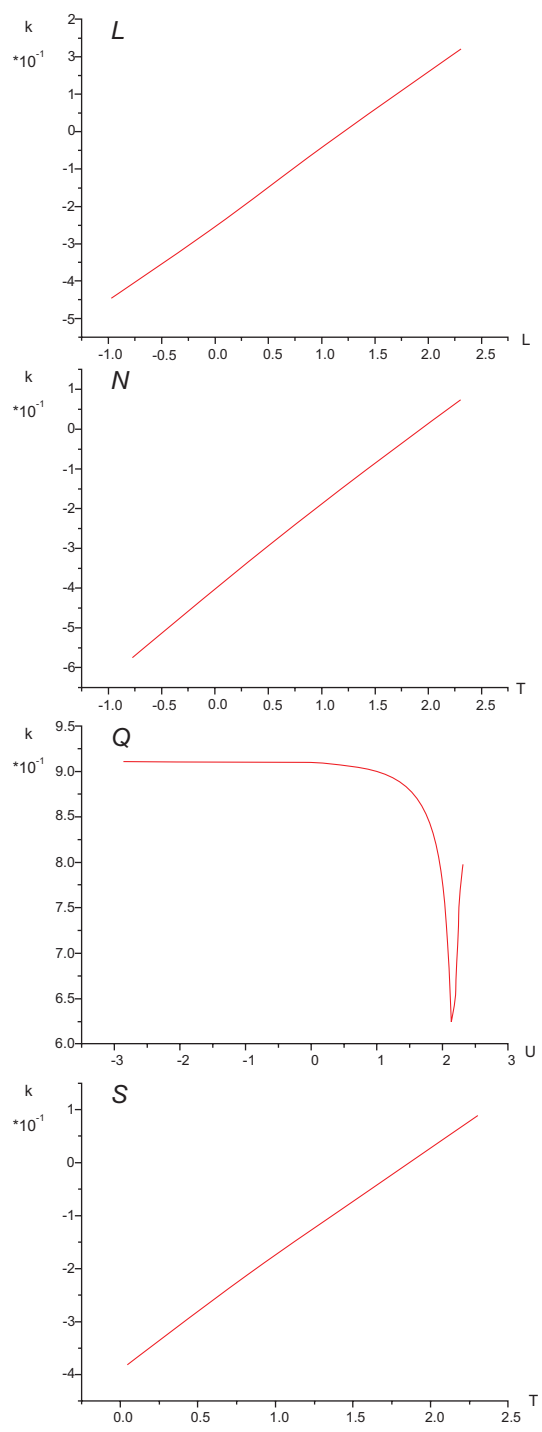
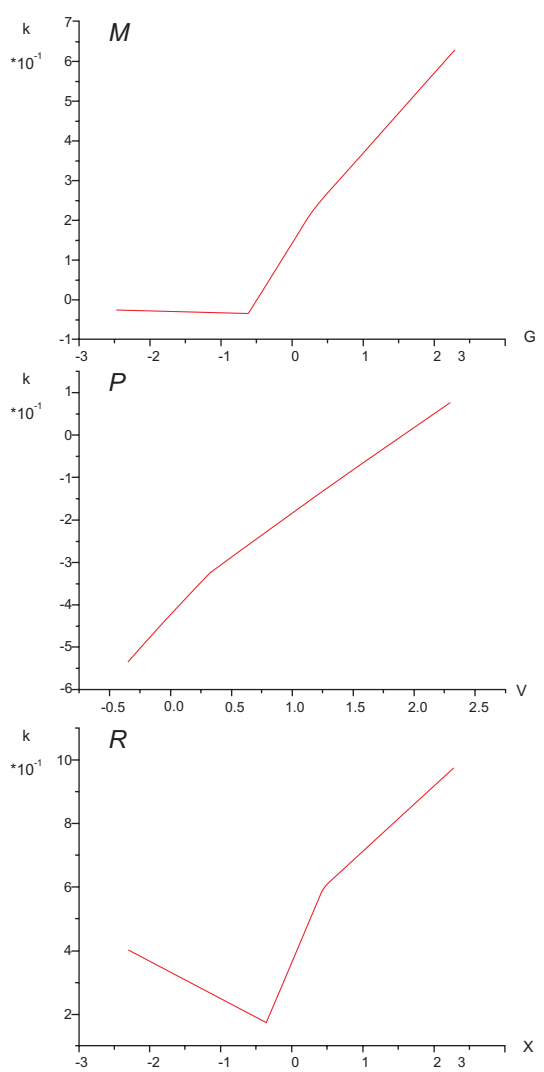

Fig. 10. Linearized response surfaces for reaction rate constants of changes in genetic controlling systems in the cells in the state of differentiation: $k_{1}^{\prime}(L) ; k_{2}^{\prime}$ $(M) ; k_{3}^{\prime}(N) ; k_{4}^{\prime}(P) ; k_{5}^{\prime}(Q) ; k_{6}^{\prime}(R) ; k_{7}^{\prime}(S)$

Рис. 10. Лінеаризовані поверхні відклику для констант швидкостей перетворень у системах генетичного контролю клітин у стані диференціації: $k^{\prime}{ }_{1}(L)$; $k_{2}^{\prime}(M) ; k_{3}^{\prime}(N) ; k_{4}^{\prime}(P) ; k_{5}^{\prime}(Q) ; k_{6}^{\prime}(Q) ; k_{7}^{\prime}(S)$

As shown in Fig. 11 when cell is in the state of proliferation, which is accompanied by an increase in the transmembrane potential of the cell, it is seen an increase of the expression of histone genes and transport proteins genes; and the concentration of fibroblast growth factor, hepatocyte growth factor, bone morphogenesis protein and factor MyoD. On the other hand, it is seen a decrease of the expression of transcription proteins genes, and therefore, the concentration of transcription factors and cyclin A, RB-regulated protein, BAF, IRF. Expression of proliferation-stimulating proteins genes and concentration of cyclin-dependent kinases remains unchanged or these changes are minor. The intensity of the expression of cell cycle genes first increases and then decreases.

When the cell is in the state of differentiation (Fig. 12) which is accompanied by a decrease in the transmembrane potential of the cell, it is seen an increase in the expression of cell cycle genes. In contrast, it is seen a decrease in the expression of transcription 


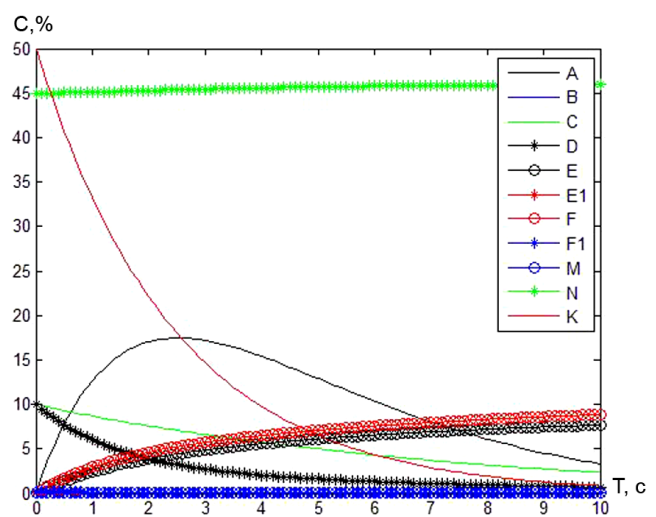

Fig. 11. Time changes in the parameters intensity of the kinetic model of changes in genetic controlling systems of the cells in the state of proliferation at defined $k_{\max }$

Рис. 11. Зміна з часом інтенсивності параметрів кінетичної моделі змін систем генетичного контролю клітин у стані проліферації при визначених $k_{\max }$

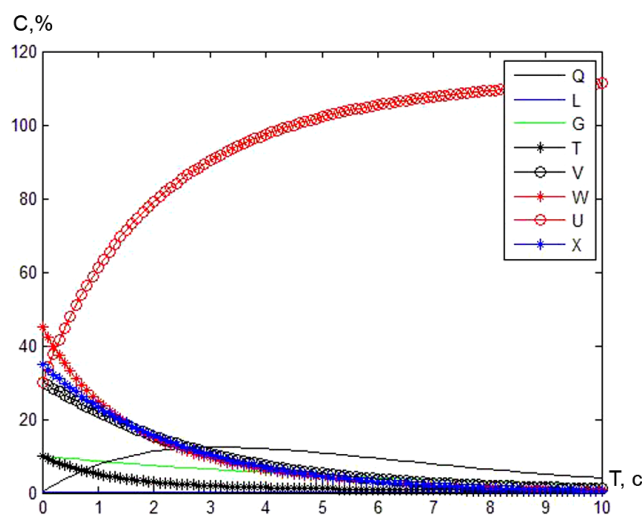

Fig. 12. Time changes in the parameters intensity of the kinetic model of changes in genetic controlling systems of the cells in the state of differentiation at defined $k_{\max }$

Рис. 12. Зміна з часом інтенсивності параметрів кінетичної моделі змін систем генетичного контролю клітин у стані диференціації при визначених $k_{\max }$

proteins genes and structural genes, and thus the concentration of transcription factors and structural proteins. The concentration of inhibitors of cyclin-dependent kinases as the concentration of cyclin-dependent kinases during cell proliferation remains unchanged or these changes are minor.

\section{CONCLUSIONS}

1. Kinetic model was built for changes in genetic controlling systems of the cells in the state of proliferation and differentiation that reflects changes in the expression of the genetic apparatus of the cell, which is in a state of proliferation, and during the onset of differential program. This model shows that changes in the cells in the state of proliferation and differentiation occur at the gene, chromosomal, cell and membrane levels.

2. Mathematical description was done for the kinetic models of changes in the genetic controlling systems of cells in the state of proliferation and differentiation in the form of differential equations systems. At the decision of which using methods of numerical integration, it was found that all the processes involved to some extent in the genetic control of cell proliferation and differentiation occur at maximal values of reaction rate constants of these changes.

3. Response surfaces were constructed for reaction rate constants of changes in genetic controlling systems of cells in the state of proliferation and differentiation, so that it was found that in the cells in the state of proliferation the biggest impact on the rate of passage of reactions have the expression of histone genes and concentration of cyclindependent kinases and in the cells in the state of differentiation - inhibitors of cyclindependent kinases. Therefore we can say that the correlation in the cell of cyclin-dependent kinases and inhibitors of cyclin-dependent kinases is a kind of trigger mechanism that launches in the cell proliferative or differential program.

4. After the digitization and linearization of response surfaces, it was determined the numerical value of $k_{\max }$ for each of the reaction rate constants that reflect changes in the genetic controlling systems in the cells in the state of proliferation and differentiation.

ISSN 1996-4536 (print) • ISSN 2311-0783 (on-line) • Біологічні Студії / Studia Biologica • 2015 • Том 9/№1 • С. 67-84 
5. Considering the exact numerical values of $k_{\max }$ it was graphically displayed the time changes of all the parameters of the kinetic model, based on which it can be argued that the cells in the state of proliferation, which is accompanied by an increase in the transmembrane potential of the cell, have increased expression of histone genes and transport proteins genes; and concentrations of fibroblast growth factor, hepatocyte growth factor, bone morphogenesis protein and factor MyoD, whereas decreased expression of transcription proteins genes, and therefore, the concentrations of transcription factors and cyclin A, RB-regulated protein, BAF, IRF. Expression of proliferation-stimulating proteins genes and concentration of cyclin-dependent kinases remains unchanged or these changes are minor. The intensity of the expression of cell cycle genes first increases and then decreases. When the cell is in the state of differentiation which is accompanied by a decrease in the transmembrane potential of the cell, it is seen an increase in the expression of cell cycle genes; and in contrast, a decrease in the expression of transcription proteins genes and structural genes, and thus the concentration of transcription factors and structural proteins. The concentration of inhibitors of cyclin-dependent kinases as the concentration of cyclin-dependent kinases during cell proliferation remains unchanged or these changes are minor.

1. Allen R.E. Hepatocyte growth factor activates quiescent skeletal muscle satellite cells in vitro. Journal of Cellular Physiology, 1995; 165: 307-312.

2. Binggeli R. Membrane potentials and sodium channels: Hypotheses for growth regulation and cancer formation based on changes in sodium channels and gap junctions. Journal of Theoretical Biology, 1986; 123: 377-401.

3. Canalis E. Bone Morphogenetic Proteins, Their Antagonists, and the Skeleton. Endocr. Rev, 2003; 24: 218-235.

4. Cone C.D. Unified theory on the basic mechanism of normal mitotic control and oncogenesis. Journal of Theoretical Biology, 1971; 30: 151-181.

5. Csete M.E. Reverse engineering of biological complexity. Science, 2002; 295: 1664-1665.

6. De Jong $\mathrm{H}$. Modeling and simulation of genetic regulatory systems: a literature review. Journal of Computational Biology, 2002; 9: 67-103.

7. Floss T. A role for FGF-6 in skeletal muscle regeneration. Genes Dev, 1997; 11: 2040-2051.

8. Füchtbauer E.M. MyoD and myogenin are coexpressed in regenerating skeletal muscle of the mouse. Developmental Dynamics: An Official Publication of the American Association of Anatomists, 1992; 193: 34-39.

9. Grounds M.D. Identification of skeletal muscle precursor cells in vivo by use of MyoD1 and myogenin probes. Cell and Tissue Research, 1992; 267: 99-104.

10. Ho L. An embryonic stem cell chromatin remodeling complex, esBAF, is essential for embryonic stem cell self-renewal and pluripotency. Proceedings of the National Academy of Sciences, 2009; 106: 5181-5186.

11. Ingalls $B$. Mathematical modelling in systems biology. Applied Mathematics, 2012. $312 \mathrm{p}$.

12. Kai $X$. Identification of proliferation/differentiation switch in the cellular network of multicellular organisms. Plos Computational Biology, 2006; 4: 124-148.

13. Kastner S. Gene Expression Patterns of the Fibroblast Growth Factors and Their Receptors During Myogenesis of Rat Satellite Cells. Journal of Histochemistry and Cytochemistry, 2000; 48: 1079-1096.

14. Lee D.K. Androgen receptor enhances myogenin expression and accelerates differentiation. Biochemical and Biophysical Research Communications, 2002; 294: 408-413.

15. Minoo P. Loss of Proliferative Potential during Terminal Differentiation Coincides with the Decreased Abundance of a Subset of Heterogeneous Ribonuclear Proteins. J. Cell Biol, 1989; 109: 1937-1946.

ISSN 1996-4536 (print) •ISSN 2311-0783 (on-line) • Біологічні Студії / Studia Biologica • 2015 • Том 9/№1 • C. 67-84 
16. Mykshyna V. S. Mathematical models in health reservation. Mathematical Modeling, 2009; 21: 111-121 (In Russian).

17. Putney L.K. Na-H Exchange-dependent Increase in Intracellular $p H$ Times $\mathrm{G}_{2} / \mathrm{M}$ Entry and Transition. Journal of Biological Chemistry, 2003; 278: 44645-44649.

18. Rubin A.B. Kinetics of biological processes. Soross Educational Journal, 1998; 10: 84-91. (In Russian).

19. Samsonova M. NetWork: An interactive interface to the tools for analysis of genetic network structure and dynamics. Proc. Pac. Symp. Biocomput. (PSB'99), 1999; 4: 102-111.

20. Seale P. Pax7 is required for the specification of myogenic satellite cells. Cell, 2000; 102: 777-786.

21. Sheehan S.M. Skeletal muscle satellite cell proliferation in response to members of the fibroblast growth factor family and hepatocyte growth factor. J. Cell Physiol, 1999; 181: 499-506.

22. Shidlovskiy N.P. Theorey and methodology development of a system mobiled pharmacy complexed. Alphabitmedical, 2005; 8: 24-26.

23. Stein L.J. Control of cell cycle regulated histone genes during proliferation and differentiation. Int. J. Obes. Relat. Metab. Disord, 1996; 3: 84-90.

24. Sundelacruz S. Membrane Potential Controls Adipogenic and Osteogenic Differentiation of Mesenchymal Stem Cells. PLoS ONE, 2008; 3: 325-342.

25. Sundelacruz S. Role of Membrane Potential in Regulation of Cell Proliferation and Differentiation. Stem. Cell Rev. and Rep, 2009; 5: 231-246.

26. Tatsumi R. HGF/SF Is Present in Normal Adult Skeletal Muscle and Is Capable of Activating Satellite Cells. Developmental Biology, 1998; 194: 114-128.

27. Tatsumi R. Release of Hepatocyte Growth Factor from Mechanically Stretched Skeletal Muscle Satellite Cells and Role of $\mathrm{pH}$ and Nitric Oxide. Molecular Biology of the Cell, 2002; 13 : 2909-2918.

28. Yablonka-Reuveni Z. Fibroblast Growth Factor Promotes Recruitment of Skeletal Muscle Satellite Cells in Young and Old Rats. Journal of Histochemistry and Cytochemistry, 1999; 47: 23-42.

29. Yablonka-Reuveni Z. Temporal expression of regulatory and structural muscle proteins during myogenesis of satellite cells on isolated adult rat fibers. Developmental Biology, 1994; 164 : 588-603.

30. Zammit P.S. Muscle satellite cells adopt divergent fates: a mechanism for self-renewal. The Journal of Cell Biology, 2004; 166: 347-357.

31. Zavitz K. Controlling cell proliferation in differentiating tissues: genetic analysis of negative regulators of G,-S-phase progression. Current Opinion in Cell Biology, 1997; 9: 773-781.

32. Zien A. Analysis of gene expression data with pathway scores. Proc. $\mathbf{8}^{\text {th }}$ Int. Conf. Intell. Syst. Mol. Biol. (ISMB 2000), 2000; 8: 407-417.

\title{
АНАЛІТИЧНИЙ ОПИС СИСТЕМ ГЕНЕТИЧНОГО КОНТРОЛЮ КЛІТИН У СТАНІ ПРОЛІФЕРАЦІЇ ТА ДИФЕРЕНЦІАЦІЇ
}

\author{
І. В. Стадник, Д. І. Санагурський \\ Львівський національний університет імені Івана Франка \\ вул. Грушевського, 4, Львів 79005, Україна \\ e-mail: irysjastadnyk@gmail.com
}

У роботі представлено кінетичні моделі змін систем генетичного контролю клітин у стані проліферації та диференціації. З'ясовано, що зміни в системах генетичного контролю клітин у стані проліферації та диференціації відбуваються при максимальних константах швидкостей реакцій. Для кожної з констант швидкостей побудовано поверхні відклику, які показують, котрі з параметрів моделі роблять

ISSN 1996-4536 (print) • ISSN 2311-0783 (on-line) • Біологічні Студії / Studia Biologica • 2015 • Том 9/№1 • C. 67-84 
найбільший внесок у величину кожної з констант. Встановлено, що найбільший внесок у константи швидкостей реакцій перетворень у системах генетичного контролю клітин у стані проліферації вносять гени гістонів і циклінзалежні кінази, а трохи менший - гени-стимулятори проліферації і транскрипційні фрактори; у клітинах у стані дифреренціації - інгібітори циклінзалежних кіназ, і рівною мірою транскрипційні фрактори, гени клітинного циклу, гени транскрипції, структурні гени та гіперполяризація клітинної мембрани. У результаті одержано дані, які свідчать про те, що співвідношення в клітині концентрації циклінзалежних кіназ та інгібіторів циклін-залежних кіназ $є$ пусковим механізмом, що визначає у клітині проліфреративну чи диференційну програму. Визначено конкретні числові значення кожної з констант швидкостей реакцій, за яких відбуваються перетворення в системах генетичного контролю клітин у стані проліферації та диференціації.

Ключові слова: проліферація, диференціація, константа швидкості, поверхня відклику, генетичний контроль.

\section{АНАЛИТИЧЕСКОЕ ОПИСАНИЕ СИСТЕМ ГЕНЕТИЧЕСКОГО КОНТРОЛЯ КЛЕТОК В СОСТОЯНИИ ПРОЛИФЕРАЦИИ И ДИФФЕРЕНЦИАЦИИ}

\section{И. В. Стадник, Д. И. Санагурский}

Львовский национальный университет имени Ивана Франко ул. Грушевского, 4, Львов 79005, Украина e-mail: irysjastadnyk@gmail.com

В работе представлены кинетические модели изменений систем генетического контроля клеток в состоянии пролиферации и дифференциации. Показано, что изменения в системах генетического контроля клеток в состоянии пролиферации и диффреренциации происходят при максимальных константах скоростей реакций. Для каждой из констант скоростей построены поверхности отклика, которые показывают, какие из параметров модели вносят наибольший вклад в величину каждой из констант. Установлено, что наибольший вклад в константы скоростей реакций преобразований в системах генетического контроля клеток в состоянии пролиферации вносят гены гистонов и циклинзависимые киназы, а несколько меньший - гены-стимуляторы пролиферации и транскрипционные факторы; в клетках в состоянии дифференциации - ингибиторы циклинзависимых киназ, и в равной степени транскрипционные фракторы, гены клеточного цикла, гены транскрипции, структурные гены и гиперполяризация клеточной мембраны. В результате получены данные, свидетельствующие о том, что соотношение в клетке концентрации циклинзависимых киназ и ингибиторов циклинзависимых киназ является пусковым механизмом, определяющим в клетке пролиферативную или дифференциальную программу. Определены конкретные числовые значения каждой из констант скоростей реакций, при которых происходят преобразования в системах генетического контроля клеток в состоянии пролиферации и дифференциации.

Ключевые слова: пролиферация, дифференциация, константа скорости, поверхность отклика, генетический контроль.

Одержано: 26.02.2015

ISSN 1996-4536 (print) • ISSN 2311-0783 (on-line) • Біологічні Студії / Studia Biologica • 2015 • Том 9/№1 • C. 67-84 